\title{
Consumer demographics and geographics: Determinants of retail success for online auctions
}

Received (in revised form): 2nd March, 2007

\begin{abstract}
Gregory S. Black
is a tenured associate professor of Marketing at Texas A\&M University - Corpus Christi. He received his PhD in marketing from Washington State University in 1996, his MBA from Brigham Young University in 1986 and his BA in International Relations and the Korean Language from Brigham Young University in 1984. His research interests include e-marketing, consumer behaviour, marketing strategy, international marketing and business education.
\end{abstract}

Keywords online auctions, consumer demographics, consumer geography, eBay, e-commerce

\begin{abstract}
This study investigates transactions of two eBay sellers of consumer goods to determine if certain demographics and geographics related to individual American consumers can be utilised to predict retail sales and the average value of those sales. The average value of each sale is equivalent to the sum of the amount bid for each item and the shipping cost for that item. A sample of 753 transactions of these two eBay retailers was analysed. The significant variables include consumer gender, whether the consumer lives in a rural or urban area and the region in the US in which the consumer resides. The implications of these results are significant to both eBay retailers and scholars alike as this study presents findings that bring us nearer to understanding consumer internet buying behaviour.

Journal of Targeting, Measurement and Analysis for Marketing (2007) 15, 93-102. doi:10.1057/palgrave.jt.5750035
\end{abstract}

\section{INTRODUCTION}

Electronic commerce is becoming increasingly more important to both sellers and buyers, including large corporations. Although still considered to be in its infancy, internet usage and online marketing are growing explosively. During 2003, approximately 40 million households in the US alone made at least one consumer purchase from the internet, up from only six million in 1994. ${ }^{1}$ Online retailing has become, and will continue to become, a full and complete business model for some companies. Internet firms such as

Correspondence: Gregory S. Black, College of Business,

Texas A\&M University - Corpus Christi,

6300 Ocean Drive,

Corpus Christi,

Texas 78412, USA.

Tel: (361) 825-3619;

Fax: (361) 825-5609;

Email: gblack@cob.tamucc.edu
Amazon.com, eBay, Yahoo! and Netscape, have proven that this type of business model can be very successful.

One of the most powerful of the many players in e-commerce is eBay. According to eBay's recent report of its 2005 financial results, it had approximately $\$ 4.552 \mathrm{bn}$ in revenue in 2005 , up 39 per cent from 2004. In addition, 1.9 billion products were listed for sale on eBay in 2005 and the total value of all successfully closed listings on eBay was a record $\$ 44.3 \mathrm{bn}$. eBay has grown faster than any other company in history, including Microsoft, Dell and Wal-Mart. Some 71.8 million active users bought and sold merchandise on eBay in $2005 .^{2}$ This is more than the gross domestic product of over half of the world's countries. If eBay was a brick-and-mortar retailer, rather than the world's largest online marketplace, it would be larger than Best Buy and Lowe's. If eBay actually employed the $500,000+$ people who earn all or 
most of their income selling on the site, it would be the second largest employer on the FORTUNE 500, with only Wal-Mart employing more people.

Consumers are also increasingly finding the value of utilising eBay to obtain items more inexpensively, more conveniently, etc. As the economy continues to be in a state of flux and consumers are uncertain about gas prices, the future of interest rates, etc, will they turn more to eBay as a means of reducing financial risk? If some increase their utilisation of eBay and some do not, what factors can be utilised as reliable predictors of consumer participation on eBay?

This research uses transaction data from two current eBay sellers. One of the sellers is a fulltime online retailer and uses eBay as the primary source of income, while the other seller uses consumer sales on eBay to supplement income. The mailing zip code of each consumer is used to collect the data and each transaction is considered to be an independent case so that the details of the transaction can be examined. Specific data were generated for each case, such as the gender of the buyer, whether the buyer lives in a rural or urban area, in which of the six US regions the buyer resides and the value of the transaction. These data provide the information necessary to achieve the objectives of this research - to examine certain geographic and demographic determinants of eBay consumers to determine if these factors have an impact on their eBay purchasing behaviour.

\section{LITERATURE REVIEW}

It is clear that eBay itself is doing what it can to increase its revenues, but it also seems to be buying into the relatively new concept of relationship marketing. eBay wants to design itself in such a way that both buyers and sellers can use and benefit from it as much as possible. Some research shows indicates that these tools provided by eBay are being used effectively by sellers. For example, the use of pictures causes more early bids on auction items and these early bids cause more bidding activity during the lifetime of the auction. ${ }^{3}$ Other research is more specific about the usage of pictures and distinguishes between the usage of stock pictures and actual pictures, suggesting that actual pictures tend to be more effective. ${ }^{4}$ The use of secret reserve prices has also been examined, ${ }^{5}$ as has sellers' ratings ${ }^{6}$ and the forums provided by eBay that give other eBay consumers the opportunity to interact with one another. ${ }^{7}$ Therefore, eBay is doing its part; however, there are many factors outside of eBay's control that impact eBay consumer behaviour.

Recent research shows that consumer demographics, such as location of residence, gender, age, etc, is helpful in predicting eBay utilisation. $^{8-10}$ Other factors are also likely to be related to individual consumers' utilisation of eBay, such as their personalities and attitudes.

Advances in technology and increasing ease of using the internet are leading to a proliferation of online business. Consumers who have access to computers can now research products easily and in a fraction of the time that was required in the past. A considerable gap, however, exists between the practice of internet-based marketing and sound theory-based insights and principles for guiding that practice. Parasuraman and Zinkhan ${ }^{11}$ suggest that understanding online customer behaviour is one of the key factors causing this gap. Other factors these authors suggest, and factors that influence online consumer, are marketing mix differences on the internet, customer loyalty, online relationship marketing, e-tailing issues and online delivery of services. ${ }^{11}$

In a study of internet pharmacies, Yang et al. ${ }^{12}$ identified and examined six dimensions of consumer perceptions of service quality. These included ease of use, content on the website, accuracy of the content, timeliness of responses, aesthetics or attractiveness of the site and privacy. Other researchers also echo concerns over similar issues that have a significant impact on online consumer behaviour. For example, there is concern among consumers for being able to assure the security and privacy of internet transactions. ${ }^{13,14}$ Also, managing customer relations and influence on consumer behaviour through effective online communication has been examined. ${ }^{15}$ Further, the ease of navigating a website has been shown to influence consumer behaviour. ${ }^{16}$ Another study provided evidence 
that the content of the website was a factor in determining consumer behaviour and satisfaction. ${ }^{17}$ There have even been attempts to identify what the differences should be in the marketing mix for online businesses. ${ }^{18}$ These factors are directly controllable by the businesses sponsoring the websites and eBay, for one, does as much as it can to excel in these dimensions in order to increase the likelihood that consumers will make purchases. Certain factors that online retailers cannot control, however, such as consumer geographics and demographics, also have the potential to significantly impact the behaviour of online consumers.

\section{Consumer characteristics and online shopping behaviour}

A recent study identified four categories of online shoppers and four categories of online nonshoppers, along with characteristics for each of these eight categories. ${ }^{19}$ Characteristics shared by these online consumers (about 42 per cent of the US population) were average household incomes of $\$ 58,300-\$ 64,400$, average ages of 44.0-49.6 years, above average education levels, an enjoyment of web browsing, a preference for merchandise being delivered to their homes, a desire for keeping purchases private, a propensity to search for the lowest prices possible, a sensitivity to high shipping prices and a concern about online credit card risk. ${ }^{19}$

\section{Auction buying behaviour}

Although auctions have been examined extensively in disciplines such as economics, and to some degree in marketing, online auctions are only beginning to receive research attention. Further, in both economics and marketing, the research on auctions has relied primarily on rational, economic theories. ${ }^{20}$ The findings of this research are, however, inconsistent. The findings from the few studies of online auctions, especially from the purchasers' perspective, are not only inconsistent, but are negligible, with only a few examples of sizable studies. For example, Haubel and Popkowski-Leszczyc ${ }^{21}$, conducted a large field study using eBay and manipulating certain variables to examine general factors related to auctions in general, but not to online auctions specifically.

\section{Consumers residing in six US regions}

Americans often speak of their country as one of several regions. These regions are cultural units rather than governmental units formed by history and geography and shaped by the economics, literature, customs and traditions that all the parts of the region share. What makes one region different from another? A region's multicultural heritage as well as distinct demographic characteristics, such as age, resources and industries, make regions unique. Within several US regions, language is used differently and there are strong dialects. There are also differences in outlook and attitude based on geography. ${ }^{22}$

New England includes the following states: Connecticut, Maine, Massachusetts, New Hampshire, Rhode Island and Vermont. It has played a dominant role in American history. Until well into the 19th century, New England was the country's cultural and economic centre. The earliest European settlers of New England were English Protestants who came in search of religious liberty. They gave the region its distinctive political format (town meetings), which were an outgrowth of meeting held by church elders, in which citizens gathered to discuss issues of the day. Education is another of the region's strongest legacies. Without, however, large expanses of rich farmland or a mild climate, many New England settlers turned from farming to other pursuits. In their business dealings, New Englanders have a reputation for hard work, shrewdness, thrift and ingenuity. ${ }^{22}$ As can be seen in Table 1, New England contains 4.88 per cent of the population of the United States. ${ }^{23}$

The Mid-Atlantic includes the following states: Delaware, Maryland, New Jersey, New York and Pennsylvania. If New England provided the brains and dollars for 19th century American expansion, the Mid-Atlantic states provided the muscle. The region's largest states - New York and Pennsylvania - became centres of heavy industry. This region was settled by a wider range of people than was New England. Into this area of 
Table 1: Summary of population and eBay data

\begin{tabular}{|c|c|c|c|c|c|}
\hline Variable & $\begin{array}{l}\% \text { of US } \\
\text { population }\end{array}$ & $\begin{array}{l}\text { \# of eBay } \\
\text { purchases }\end{array}$ & $\begin{array}{l}\% \text { of total } \\
\text { purchase }\end{array}$ & $\$$ value of purchases & $\begin{array}{l}\% \text { of total } \\
\text { purchase }\end{array}$ \\
\hline \multicolumn{6}{|l|}{ Region } \\
\hline New England & 4.88 & 21 & 2.79 & $\$ 284.85$ & 2.46 \\
\hline Mid-Atlantic & 16.22 & 85 & 11.29 & $\$ 1,057.10$ & 9.12 \\
\hline South & 24.69 & 190 & 25.23 & $\$ 2,991.94$ & 25.81 \\
\hline Midwest & 22.58 & 241 & 32.01 & $\$ 3,639.46$ & 31.40 \\
\hline Southwest & 11.32 & 90 & 11.95 & $\$ 1,527.63$ & 13.18 \\
\hline West & 20.32 & 126 & 16.73 & $\$ 2,090.49$ & 18.03 \\
\hline \multicolumn{6}{|l|}{ Rural/Urban } \\
\hline Urban & 83 & 373 & 49.54 & $\$ 6,201.97$ & 53.50 \\
\hline Rural & 17 & 380 & 50.46 & $\$ 5,389.50$ & 46.50 \\
\hline \multicolumn{6}{|l|}{ Gender } \\
\hline Male & 48.85 & 245 & 32.54 & $\$ 4,361.44$ & 37.63 \\
\hline Female & 51.15 & 508 & 67.46 & $\$ 7,230.03$ & 62.37 \\
\hline
\end{tabular}

industry came millions of Europeans who made of it what became known as the 'melting pot'. As heavy industry spread throughout the region, major rivers in the area were transformed into vital shipping lanes. Cities on waterways grew dramatically. New York is still the nation's largest city, the nation's financial hub and its cultural centre. Even today, the visitor who expects only factories and crowded cities is surprised. In the Mid-Atlantic, there are more wooded hills than factory chimneys, more fields than paved roads and more farmhouses than office buildings. ${ }^{22}$ As can be seen in Table 1, the Mid-Atlantic contains 16.22 per cent of the population of the United States. ${ }^{23}$

The South includes the following states: Alabama, Arkansas, Florida, Georgia, Kentucky, Louisiana, Mississippi, North Carolina, South Carolina, Tennessee, Virginia and West Virginia. This region is perhaps the most distinctive region of the United States. The American Civil War devastated the Old South socially and economically. Slavery was the issue that divided the North and the South. To northerners, slavery was immoral, but to southerners, it was integral to their way of life and their plantation system of agriculture. The scars left by the war took decades to heal and some of the attitudes existing both before and during the war still exist today. The 'new' South has evolved into a manufacturing region and high-rise buildings crowd the skylines of its large cities. The region is also blessed with plentiful rainfall and a mild climate. Crops grow easily in its soil and can be grown without frost for at least six months of the year. Owing to its mild weather, the South has become a mecca for retirees from other regions. ${ }^{22}$ As can be seen in Table 1, the South contains 24.69 per cent of the population of the United States. ${ }^{23}$

The Midwest includes the following states: Illinois, Indiana, Iowa, Kansas, Michigan, Minnesota, Missouri, Nebraska, North Dakota, Ohio, South Dakota and Wisconsin. This region is known as the nation's 'breadbasket'. The fertile soil of the region makes it possible for farmers to product abundant harvests of cereal crops. Corn is the most important of all American crops and the annual harvest of corn in this region exceeds the annual harvest of wheat, rice and other grains combined. Farms are normally located separate from one another, close to fields and often beyond the sight of neighbours. The town is principally a place where the farm family travels to buy supplies, to attend church and to go for entertainment or political, social or business meetings. Midwesterners are praised as being open, friendly and straightforward. Their politics tend to be cautious, but the caution is sometimes peppered with protest. ${ }^{22}$ As can be seen in Table 1, the Midwest contains 22.58 per cent of the population of the United States. ${ }^{23}$

The Southwest includes the following states: Arizona, New Mexico, Oklahoma and Texas. This region's climate is drier than is that of the 
adjoining Midwest. The population is less dense and, with strong Hispanic-American and NativeAmerican components, is more ethnically varies than neighbouring areas. Outside the cities, the region is a land of open spaces, much of which is desert. The population of the region is growing rapidly and portions of it now rival parts of the South as a destination for retirees in search of warm climates. Through irrigation, the land is being increasingly utilised for crops and through damming some of the major rivers flowing through the region, once small town have become major cities. ${ }^{22}$ As can be seen in Table 1, the Southwest contains 11.32 per cent of the population of the United States. ${ }^{23}$

The West includes the following states: Alaska, Colorado, California, Hawaii, Idaho, Montana, Nevada, Oregon, Utah, Washington and Wyoming. Americans have long regarded the West as the last frontier; yet, California has a history of European settlement older than that of most of the Midwestern states. In much of the West, the population is sparse and the federal government owns and manages millions of square miles of undeveloped land. Americans use these areas for recreational and commercial activities. Hawaii is the only state in the union in which Asian Americans are the largest ethnic group. The region is also known to have a large MexicanAmerican population. The second largest city in the nation - Los Angeles - is known to be the entertainment capital of the world, while other area of the west have nurtured and fostered the computer age and explosion of technology. Over the history of the West, people from outside the region have moved there to make a new start. As a result, many Western cities are known for their tolerance and a very strong 'live-and-let-live' attitude. ${ }^{22}$ As can be seen in Table 1, the West contains 20.32 per cent of the population of the United States. ${ }^{23}$

Because of the cultural differences between these regions of the United States, the researcher expects consumers to behave differently when utilising eBay to obtain needed/wanted products. This research examines consumer differences in several areas. First, the proportion of the number of purchases made in each region to the total number of purchases was compared to the proportion of the US population residing in each region. Secondly, the proportion of the value of the purchases made in each region to the total value to the total value of all purchases was compared to the proportion of the US population residing in each region. Thirdly, the differences between the number of purchases and the value of the purchases were examined to determine if people in each region spent significantly more per purchase. Fourthly, the average price paid for an item in each region was compared to further determine if people in each region spent significantly more per purchase than people in other regions.

\section{Consumers residing in urban or rural areas}

The US Census Bureau classifies as 'urban' all territory, population and housing units located within a core census block group that has a population density of at least 1,000 people per square mile and surrounding census blocks have an overall density of at least 500 people per square mile. The Census Bureau's classification of 'rural' consists of all territory, population and housing units located outside these urban areas. People residing in urban areas may have more access to brick-and-mortar stores where namebrand items can be more easily purchased than people residing in rural areas. Table 1 shows that 83 per cent of the nation's population resides in urban areas, while 17 per cent resides in rural areas.

Because of the cultural differences between these urban and rural areas and possible differences in access to products, the researcher expects consumers to behave differently when utilising eBay to obtain needed/wanted products. One important factor leading to these expectations is related to consumer experience with the internet. It is likely that consumers in urban areas will have more experience with the internet than do consumers residing in rural areas. One reason for this is that the availability of the internet, especially high-speed or broadband internet, will be less in rural areas. Research has shown that lack of experience with the internet 
results in more reluctance to use the internet to participate in online auctions. ${ }^{24}$

This research examines consumer differences in several areas. First, the proportion of the number of purchases made in each type of area to the total number of purchases was compared to the proportion of the US population residing in each type of area. Secondly, the proportion of the value of the purchases made in each type of area to the total value of all purchases was compared to the proportion of the US population residing in each type of area. Thirdly, the differences between the number of purchases and the value of the purchases were examined to determine if people in each type of area spent significantly more per purchase. Fourthly, the average price paid for an item in each type of area was compared to further determine if people in each type of area spent significantly more per purchase than people in the other type of area.

\section{Consumer gender}

Because of commonly known differences between male and female consumer when they are making purchase decisions at brick-and-mortar stores, similar differences may occur when consumers shop and make purchase decisions on eBay. Table 1 shows that 51.15 per cent of the population of the US are females and 48.85 per cent of the population are males. Because of these expected gender differences, the researcher expects consumers to behave differently when utilising eBay to obtain needed/wanted products.

It has been suggested in earlier studies that women use the internet less than do men. ${ }^{19}$ Because of this phenomenon, women are likely to exhibit differences in their participation in online auctions, such as eBay. In fact, research has shown that people with less internet experience will be less likely to participate in online auctions. ${ }^{24}$

This research examines consumer differences in several areas. First, the proportion of the number of purchases made by each gender to the total number of purchases was compared to the proportion of the US population in each gender. Secondly, the proportion of the value of the purchases made by each gender to the total value of all purchases was compared to the proportion of the US population in each gender. Thirdly, the differences between the number of purchases and the value of the purchases made by each gender were examined to determine if people of each gender spent significantly more per purchase. Fourthly, the average price paid for an item by each gender was compared to further determine if people of each gender spent significantly more per purchase than people of the other gender.

\section{RESULTS}

\section{Regions}

Table 1 reveals differences in population proportions and the proportion of eBay purchases. New England contains 4.88 per cent of the population and accounted for 2.79 per cent of the total number of eBay purchases, while accounting for 2.46 per cent of the total value of those eBay purchases. Table 2 indicates that the differences of both the number of purchases $(z=2.66, p=0.0039)$ and the value of the purchases $(z=3.08, p=0.0010)$ are statistically lower than New England's proportion of the nation's population. The difference between these two New England proportions is, however, not statistically significant, indicating that New Englanders do not spend a different amount on each purchase than do people from other regions. To further examine this relationship, Table 3 shows no significant differences between the average prices paid by New Englanders and those in other regions.

Looking at Table 1 again, the Mid-Atlantic contains 16.22 per cent of the population and accounted for 11.29 per cent of the total number of eBay purchases, while accounting for 9.12 per cent of the total value of those eBay purchases. Table 2 indicates that the differences of both the number of purchases $(z=1.65, p=0.0495)$ and the value of the purchases $(z=2.37, p=0.0089)$ are statistically lower than the Mid-Atlantic's proportion of the nation's population. Further, the difference between these two Mid-Atlantic proportions is also statistically significant, indicating that Mid-Atlantic residents spend less each purchase than do people from other regions. To further examine this relationship, Table 3 
Table 2: Results of eBay comparisons

\begin{tabular}{|c|c|c|}
\hline Variable & Comparison & Z-score \\
\hline \multicolumn{3}{|l|}{ Region } \\
\hline \multirow[t]{3}{*}{ New England } & \# of purchases & $-2.66^{\star \star \star}$ \\
\hline & Value of purchases & $-3.08^{\star \star \star}$ \\
\hline & Difference & -0.55 \\
\hline \multirow[t]{3}{*}{ Mid-Atlantic } & \# of purchases & $-1.65^{\star \star}$ \\
\hline & Value of purchases & $-2.37^{\star \star \star}$ \\
\hline & Difference & $-1.88^{\star \star}$ \\
\hline \multirow[t]{3}{*}{ South } & \# of purchases & 0.34 \\
\hline & Value of purchases & 0.71 \\
\hline & Difference & 0.37 \\
\hline \multirow[t]{3}{*}{ Midwest } & \# of purchases & $6.19^{\star \star \star}$ \\
\hline & Value of purchases & $5.79^{\star \star \star}$ \\
\hline & Difference & -0.36 \\
\hline \multirow[t]{3}{*}{ Southwest } & \# of purchases & 0.55 \\
\hline & Value of purchases & $1.61^{*}$ \\
\hline & Difference & 1.04 \\
\hline \multirow[t]{3}{*}{ West } & \# of purchases & $-2.45^{\star \star \star}$ \\
\hline & Value of purchases & $-1.56^{\star}$ \\
\hline & Difference & 0.96 \\
\hline \multicolumn{3}{|l|}{ Rural/Urban } \\
\hline \multirow[t]{3}{*}{ Urban } & \# of purchases & $-24.44^{\star \star \star}$ \\
\hline & Value of purchases & $21.55^{\star \star \star}$ \\
\hline & Difference & $-2.17^{\star \star}$ \\
\hline \multirow[t]{3}{*}{ Rural } & \# of purchases & $24.44^{\star \star \star}$ \\
\hline & Value of purchases & $-10.10^{\star \star \star}$ \\
\hline & Difference & $-2.17^{\star \star}$ \\
\hline \multicolumn{3}{|l|}{ Gender } \\
\hline \multirow[t]{3}{*}{ Female } & \# of purchases & $8.73^{\star \star \star}$ \\
\hline & Value of purchases & $6.16^{\star \star \star}$ \\
\hline & Difference & $-2.98^{\star \star \star}$ \\
\hline \multirow[t]{3}{*}{ Male } & \# of purchases & $-8.95^{\star \star \star}$ \\
\hline & Value of purchases & $-6.16^{\star \star \star}$ \\
\hline & Difference & $2.98^{\star \star \star}$ \\
\hline
\end{tabular}

*Statistically significant at $p<0.10$.

${ }^{\star}$ Statistically significant at $p<0.05$.

${ }^{* * *}$ Statistically significant at $p<0.01$.

shows significant differences between prices paid by residents of the Mid-Atlantic (less) and Southerners $(t=4.728, p=0.031)$, residents of the Mid-Atlantic (less) and Southwesterners $(t=5.038$, $p=0.026$ ), and residents of the Mid-Atlantic (less) and Westerners $(t=7.736, p=0.006)$.

Looking at Table 1 again, the South contains 24.69 per cent of the population and accounted for 25.23 per cent of the total number of eBay purchases, while accounting for 25.81 per cent of the total value of those eBay purchases. Table 2 indicates that there are no significant differences of the number of purchases and the value of the purchases to the South's proportion of the nation's population. Further, the difference between these two Mid-Atlantic proportions is also not statistically significant. Further investigation, however, shows a significant difference between prices paid by Southerners (more) and the residents of the Mid-Atlantic, as discussed in the previous paragraph (Table 3).

Looking at Table 1 again, the Midwest contains 22.58 per cent of the population and accounted for 32.01 per cent of the total number of eBay purchases, while accounting for 31.40 per cent of the total value of those eBay purchases. Table 2 indicates that the differences of both the number of purchases $(z=6.19, p=0.0000)$ and the value of the purchases $(z=5.79, p=0.0000)$ are statistically higher than the Midwest's proportion of the nation's population. The difference between these two Midwest proportions is, however, not statistically significant. Further, Table 3 shows there is no significant difference between the average prices paid by Midwesterners and people residing in other regions.

Looking at Table 1 again, the Southwest contains 11.32 per cent of the population and accounted for 11.95 per cent of the total number of eBay purchases, while accounting for 13.18 per cent of the total value of those eBay purchases. Table 2 indicates no difference between the number of purchases made in the Southwest and the Southwest's proportion of the nation's population; however, the value of the purchases $(z=1.61, p=0.0537)$ is statistically higher than the Southwest's proportion of the nation's population. The difference between these two Southwest proportions is, however, not statistically significant. Further investigation, however, shows a significant difference between prices paid by Southwesterners (more) and the residents of the Mid-Atlantic, as discussed above and indicated in Table 3.

Finally, looking at Table 1 again, the West contains 20.32 per cent of the population and accounted for 16.73 per cent of the total number of eBay purchases, while accounting for 18.03 per cent of the total value of those eBay purchases. 
Table 3: Results of average price analysis

\begin{tabular}{|c|c|c|c|}
\hline Variables compared & $N$ & $\begin{array}{l}\text { Average } \\
\text { price }\end{array}$ & $t$-value \\
\hline New England/ & 21 & $\$ 13.56$ & \\
\hline Mid-Atlantic & 85 & $\$ 12.44$ & 0.088 \\
\hline New England/ & 21 & $\$ 13.56$ & \\
\hline South & 190 & $\$ 15.75$ & 0.895 \\
\hline New England/ & 21 & $\$ 13.56$ & \\
\hline Midwest & 241 & $\$ 15.10$ & 0.25 \\
\hline New England/ & 21 & $\$ 13.56$ & \\
\hline Southwest & 90 & $\$ 16.97$ & 1.03 \\
\hline New England/ & 21 & $\$ 13.56$ & \\
\hline West & 126 & $\$ 16.59$ & 1.51 \\
\hline Mid-Atlantic/ & 85 & $\$ 12.44$ & \\
\hline South & 190 & $\$ 15.75$ & $4.728^{*}$ \\
\hline Mid-Atlantic/ & 85 & $\$ 12.44$ & \\
\hline Midwest & 241 & $\$ 15.10$ & 1.583 \\
\hline Mid-Atlantic/ & 85 & $\$ 12.44$ & \\
\hline Southwest & 90 & $\$ 16.97$ & $5.038^{*}$ \\
\hline Mid-Atlantic/ & 85 & $\$ 12.44$ & \\
\hline West & 126 & $\$ 16.59$ & $7.736^{\star \star}$ \\
\hline South/ & 190 & $\$ 15.75$ & \\
\hline Midwest & 241 & $\$ 15.10$ & 0.601 \\
\hline South/ & 190 & $\$ 15.75$ & \\
\hline Southwest & 90 & $\$ 16.97$ & 0.268 \\
\hline South/ & 190 & $\$ 15.75$ & \\
\hline West & 126 & $\$ 16.59$ & 0.046 \\
\hline Midwest/ & 241 & $\$ 15.10$ & \\
\hline Southwest & 90 & $\$ 16.97$ & 1.108 \\
\hline Midwest/ & 241 & $\$ 15.10$ & \\
\hline West & 126 & $\$ 16.59$ & 0.292 \\
\hline Southwest/ & 90 & $\$ 16.97$ & \\
\hline West & 126 & $\$ 16.59$ & 0.517 \\
\hline Urban/ & 373 & $\$ 16.63$ & \\
\hline Rural & 380 & $\$ 14.18$ & $9.853^{\star \star}$ \\
\hline Female/ & 508 & $\$ 14.25$ & \\
\hline Male & 245 & $\$ 17.89$ & $11.028^{\star \star}$ \\
\hline
\end{tabular}

*Statistically significant at $p<0.05$.

${ }^{\star \star}$ Statistically significant at $p<0.01$.

Table 2 indicates that the differences of both the number of purchases $(z=2.45, p=0.0071)$ and the value of the purchases $(z=1.56, p=0.0594)$ are statistically lower than the West's proportion of the nation's population. The difference between these two Western proportions is, however, not statistically significant, indicating that Westerners do not spend a different amount on each purchase than do people from other regions. Further investigation, however, shows a significant difference between prices paid by Westerners (more) and the residents of the Mid-Atlantic, as discussed above and indicated in Table 3.

\section{Urban/rural}

Table 1 reveals differences in proportions of the US population residing in urban or rural areas and the proportions living in those areas of eBay purchases. Urban areas of the US contain 83 per cent of the population, but accounted for only 49.54 per cent of the total number of eBay purchases, while accounting for only 53.50 per cent of the total value of those eBay purchases. Table 2 indicates that the differences of both the number of purchases $(z=24.44, p=0.0000)$ and the value of the purchases $(z=21.55, p=0.0000)$ are statistically lower than the proportion of the US population living in urban areas. Further, the difference between these two urban proportions is also statistically significant, indicating that urbanites spend a different amount on each purchase than do people from rural areas $(z=2.17, p=0.0150)$. To further examine this relationship, Table 3 also shows that $t$ testing indicates a significant difference between the average prices paid by urbanites (more) and those living in rural areas $(t=9.853, p=0.002)$.

Rural areas of the US contain only 17 per cent of the population, but accounted for as much as 50.46 per cent of the total number of eBay purchases, while accounting for 46.50 per cent of the total value of those eBay purchases. Table 2 indicates that the differences of both the number of purchases $(z=24.44, p=0.0000)$ and the value of the purchases $(z=10.10, p=0.0000)$ are statistically higher than the proportion of the US population living in rural areas. Further, the difference between these two rural proportions is also statistically significant, indicating that people residing in rural areas spend a different amount on each purchase than do people from urban areas $(z=2.17, p=0.0150)$. To further examine this relationship, Table 3 also shows that $t$ testing indicates a significant difference between the average prices paid by people from rural areas (less) and urbanites, as discussed in the previous paragraph.

\section{Gender}

Table 1 reveals differences in proportions of the US population who are females or males and the proportions of the two genders making eBay purchases. Males account for 48.85 per cent of the population, but accounted for only 32.54 per cent of the total number of eBay purchases, while 
accounting for 37.63 per cent of the total value of those eBay purchases. Table 2 indicates that the differences between both the number of purchases $(z=8.73, p=0.0000)$ and the value of the purchases $(z=6.16, p=0.0000)$ are statistically lower than the proportion of the US population who are male. Further, the difference between these two male proportions is also statistically significant, indicating that males spend a different amount on each purchase than do females $(z=2.98, p=0.0014)$. To further examine this relationship, Table 3 also shows that $t$ testing indicates a significant difference between the average prices paid by males (more) than females $(t=11.028, p=0.001)$.

Females account for 51.15 per cent of the US population, but accounted for as much as 67.46 per cent of the total number of eBay purchases and 62.37 per cent of the total value of those eBay purchases. Table 2 indicates that the differences of both the number of purchases $(z=8.95, p=0.0000)$ and the value of the purchases $(z=6.16, p=0.0000)$ are statistically higher than the proportion of the US population who are female. Further, the difference between these two female proportions is also statistically significant, indicating that females spend a different amount on each purchase than do males $(z=2.98, p=0.0014)$.

To further examine this relationship, Table 3 also shows that $t$ testing indicates a significant difference between the average prices paid by females (less) than males, as discussed in the previous paragraph.

\section{DISCUSSION AND CONCLUSIONS}

Several significant findings were discovered in this study. Consumers from different regions of the United States tend to behave differently when it comes to eBay purchasing. For example, this study clearly shows that people from both the Southwest and the West are willing to pay significantly higher prices for the same types of products. Also, people from New England, the Mid-Atlantic and the West regions are less likely to make purchases on eBay (and maybe the internet) than are people from other regions of the country. Also, people from rural areas are more likely to purchase products on eBay than are people living in urban areas, though urbanites are likely to be willing to pay higher prices for products purchases on the internet. Finally, females are more likely to purchase on eBay, while males are more likely to pay higher prices for similar items.

These findings have important implications for practitioners and researchers. To receive the highest prices for items, eBay sellers should time their auctions so they end during the prime internet time for consumers living in the Southwest and West. Experience indicates that these times are later in the evening (9:00 pm11:00pm in the Pacific and Mountain Time Zones) on Saturday during the warmer months and during the late afternoon and evening on Saturday during the colder months of the year. These times would also be best to reach men, who are willing to spend more money on each eBay purchase. Obtaining the highest price per item sold must, however, be balanced with possibly selling a higher percentage of items by selecting auction ending times compatible with areas of the country where people are more likely to make eBay purchases (the Southwest, the Midwest and the South), and with times when more women are likely to be using the internet.

One of the most interesting implications for researchers concerns the findings that compared rural and urban residents. The speculation that internet access, especially high-speed internet access is not as readily available to those living in rural areas should be confirmed as a significant factor by additional research. In addition, the speculation that urbanites have more ready access to brick-and-mortar retailers and the implication that this is a significant factor also needs to be verified through additional research. In fact, recent research shows a growing trend for rural consumers to utilise the internet for acquiring product information ${ }^{25}$ and for making actual purchases of consumer products. ${ }^{26}$ There are many additional areas of future research that might shed further light on the behaviour of eBay consumers. The eBay sellers indicated that they suspected a difference in buyer activity depending on the weather patterns in certain 
areas of the country. It would also be useful to examine other consumer demographics, such as income, education, level of crime in their communities and whether they pay over the internet or by snail mail.

This study does have limitations. The eBay sellers whose information was obtained for this study sold mostly new and used name-brand clothing. Although clothing accounts for as much as 35.3 per cent of consumer online purchases, ${ }^{19}$ these findings may not apply to other types of products being sold on eBay. Additionally, consumer behaviour regarding eBay purchasing may vary from internet purchasing in general. Finally, only US eBay retailers and consumers were examined in this study. As in the United States, eBay and other online auctions are quickly becoming popular in other countries; therefore, the results of similar studies in other countries may vary from the results of this research.

\section{Acknowledgments}

The author would like to thank Texas A\&M University - Corpus Christi for providing a faculty research grant in support of this work.

\section{References}

1 Hof, R. D. (2003) 'The eBay economy', Businessweek, August 25, pp. $125-128$.

2 Anonymous (2005) eBay Annual Report, http://investor.ebay.com.

3 Stern, B. B. and Stafford, M. R. (2006) 'Individual and social determinants of winning bids in online auctions', Journal of Consumer Behaviour, Vol. 5, No. 1, pp. 43-55.

4 Bland, E. M., Black, G. S. and Lawrimore, K. (2005) 'Determinants of effectiveness and success for eBay auctions', The Coastal Business Journal, Vol. 4, No. 1, pp. 5-15.

5 Vishwanath, A. and Barnett, G. A. (2005) 'An empirical investigation into the structure of bidding in online auctions', Electronic Markets, Vol. 15, No. 3, pp. 261-276.

6 Scmudli, G., Jank, W., Aris, A., Plaisant, C. and Shneiderman, B (2006) 'Exploring auction databases through interactive visualization', Decision Support Systems, Vol. 42, No. 3, pp. 1521-1531.

7 Cameron, D. D. and Galloway, A. (2005) 'Consumer motivations and concerns in online auctions: An exploratory study', International Journal of Consumer Studies, Vol. 29, No. 3, pp. 181-189.

8 Black, G. S. (2005a) 'Is eBay for everyone: An assessment of consumer demographics', Advanced Management Journal, Vol. 70(Winter), pp. 50-59.
9 Black, G. S. (2005b) 'Predictors of consumer trust and willingness to pay online', Marketing Intelligence and Planning, Vol. 23, No. 7, pp. 648-658.

10 Black, G. S. (2005c) 'Socio-economic determinants of participation in online auctions', Atlantic Economic Journal, Vol. 33, pp. 1-2.

11 Parasuraman, A. and Zinkhan, G. M. (2002) 'Marketing to and serving customers through the internet: An overview and research agenda', Journal of the Academy of Marketing Science, Vol. 30(Fall), pp. 286-295.

12 Yang, Z., Peterson, R. T. and Huang, L. (2001) 'Taking the pulse of internet Pharmacies', Marketing Health Services, Vol. 21, No. 2, pp. $5-10$.

13 Rust, R. T., Kannan, P. K. and Peng, N. (2002) 'The customer economics of internet privacy', Journal of the Academy of Marketing Science, Vol. 30(Fall), pp. 455-464.

14 Zeithaml, V. A., Parasuraman, A. and Malhotra, A. (2002) 'Service quality delivery through web sites: A critical review of extant knowledge', Journal of the Academy of Marketing Science, Vol. 30(Fall), pp. 362-375.

15 Stewart, D. W. and Pavlou, P. A. (2002) 'From consumer response to active consumer: Measuring the effectiveness of interactive media,', Journal of the Academy of Marketing Science, Vol. 30(Fall), pp. 376-396.

16 Luna, D., Perracchio, L. A. and de Juan, M. D. (2002) 'Crosscultural and cognitive aspects of web site navigation', Journal of the Academy of Marketing Science, Vol. 30(Fall), pp. 397-410.

17 Burke, R. R. (2002) 'Technology and the customer interface: What consumers want in the physical and virtual store', Journal of the Academy of Marketing Science, Vol. 30(Fall), pp. 411-432.

18 Kalyanam, K. and McIntyre, S. (2002) 'The e-marketing mix: A contribution of the e-tailing wars', Journal of the Academy of Marketing Science, Vol. 30(Fall), pp. 487-499.

19 Swinyard, W. R. and Smith, S. M. (2003) 'Why people (don't) shop online: A lifestyle study of the internet', Psychology $\mathcal{E}$ Marketing, Vol. 20(July), pp. 567-576.

20 Gilkeson, J. H. and Reynolds, K. (2003) 'Determinants of internet auction success and closing price: An exploratory study', Psychology \& Marketing, Vol. 20(June), pp. 537-545.

21 Haubel, G. and Popkowski-Leszczyc, P. T. L. (2000) 'Going, going, gone: Determinants of bidding behavior in auctions', unpublished working paper.

22 Anonymous (2003) 'The Regions of the United States', US Diplomatic Mission, Washington, DC.

23 Anonymous (2000) 'United States Census 2000', US Census Bureau, Washington, DC.

24 Wilcox, R. T. (2000) 'Experts and amateurs: The role of experience in internet auctions', Marketing Letters, Vol. 11, No. 4, pp. 363-370.

25 Williams, C. C. (2003) 'Participation in alternative retail channels: A choice or necessity?', International Journal of Retail $\mathcal{E}$ Distribution Management, Vol. 31, No. 4/5, pp. 235-243.

26 Johnson, K. K. P., Yoo, J. J., Rhee, J. E. and Lennon, S. (2006) 'Multi-channel shopping: Channel use among rural consumer', International Journal of Retail \& Distribution, Vol. 34, No. 6, pp. 453-464. 